\title{
Diverse hypolithic refuge communities in the McMurdo Dry Valleys
}

\author{
DON A. COWAN ${ }^{\mathbf{1}}$, NURAAN KHAN ${ }^{\mathbf{1}}$, STEPHEN B. POINTING ${ }^{\mathbf{2}}$ and S. CRAIG CARY ${ }^{\mathbf{3}}$ \\ ${ }^{I}$ Institute for Microbial Biotechnology and Metagenomics, University of the Western Cape, Bellville 7535, Cape Town, South Africa \\ ${ }^{2}$ School of Biological Sciences, The University of Hong Kong, Pokfulam Road, Hong Kong, China \\ ${ }^{3}$ Department of Biological Sciences, University of Waikato, Hamilton, New Zealand \\ dcowan@uwc.ac.za
}

\begin{abstract}
Hyper-arid deserts present extreme challenges to life. The environmental buffering provided by quartz and other translucent rocks allows hypolithic microbial communities to develop on sub-soil surfaces of such rocks. These refuge communities have been reported, for many locations worldwide, to be predominantly cyanobacterial in nature. Here we report the discovery in Antarctica's hyper-arid McMurdo Dry Valleys of three clearly distinguishable types of hypolithic community. Based on gross colonization morphology and identification of dominant taxa, we have classified hypolithic communities as Type I (cyanobacterial dominated), Type II (fungal dominated) and Type III (moss dominated). This discovery supports a growing awareness of the high biocomplexity in Antarctic deserts, emphasizes the possible importance of cryptic microbial communities in nutrient cycling and provides evidence for possible successional community processes within a cold arid landscape.
\end{abstract}

Received 25 November 2009, accepted 28 May 2010

Key words: Antarctic, cryptic, cyanobacteria, hypoliths, microbial diversity

\section{Introduction}

The Antarctic continent contains the coldest, most arid environments on Earth (Onofri et al. 2004). These environments are restricted to the ice-free regions of the continent, of which the $4800 \mathrm{~km}^{2}$ McMurdo Dry Valleys of South Victoria Land comprise the most extensive ice-free deserts in Antarctica (Vishniac 1993, Onofri et al. 2004, Cowan \& Ah Tow 2004). These deglaciated zones provide a range of biotic habitats including lakes, glacial streams, flushes, ponds, open mineral soils and stable rock surfaces (Cowan \& Ah Tow 2004). McMurdo Dry Valley desert soils have, in the past, been widely believed to support very low microbial populations (Boyd et al. 1970, Cameron et al. 1972). However, recent quantitative and phylogenetic studies have demonstrated that McMurdo Dry Valley mineral soils harbour both substantial populations of microorganisms with $10^{6}-10^{8}$ cells.g ${ }^{-1}$ (Cowan et al. 2002) and high microbial phylogenetic diversity (e.g. Smith et al. 2006, Aislabie et al. 2006).

The geology of the McMurdo Dry Valleys is complex, with mixed granite, schist and gneiss basements cross-cut with quartz and marble outcrops (Bockheim 1997). Freezethaw fragmentation of these outcrops and transport of the fragmented strata by historical glacial events has seeded much of the southern Dry Valleys with small translucent quartz stones (Broady 2005). Where these are present in the desert pavement (i.e. exposed to the surface), they support the growth of localized 'hypolithic' communities (Nienow \&
Friedmann 1993). These communities are most commonly observed as green and/or red/orange pigmented cyanobacterial layers colonizing the rock-soil interface at the base and along the sides of the translucent rocks or stones (Wood et al. 2008, Pointing et al. 2009). The advantageous microenvironmental characteristics of the hypolithic habitat, in comparison to the soil surface photic zone, are shown in Table I.

Hypolithic communities have been found in both hot (Schlesinger et al. 2003, Warren-Rhodes et al. 2006, Pointing et al. 2007) and cold (Broady 1981, Smith et al. 2000, Cockell \& Stokes 2004, Wood et al. 2008, Pointing et al. 2009) deserts, where similar conditions of extreme temperature fluctuations and aridity exist. They are typically associated with any suitable translucent mineral substrate, including quartz (Schlesinger et al. 2003), flint (Berner \& Evenari 1978), limestone (Cockell \& Stokes 2004), gypsum (Hughes \& Lawley 2003) and sandstone (Friedmann \& Ocampo 1976).

Antarctic hypolithic communities are typically described as being dominated by cyanobacteria (Broady 1981, Wood et al. 2008, Pointing et al. 2009), with commonly encountered taxa including Phormidium spp., Lyngbya spp., Chroococcidiopsisand Synechococcus-like cells (Smith et al. 2000) and Plectonema (Broady 1981). Here we present field observations which demonstrate that Antarctic hypolithons exist in different physical and compositional types. The possibility that these communities constitute stages in community development has implications for microbial adaptation and succession in polar (and other cold) habitats. 
Table I. A comparison of soil surface and hypolithic microenvironmental properties.

\begin{tabular}{|c|c|c|c|}
\hline $\begin{array}{l}\text { Disadvantageous } \\
\text { characteristics of soil } \\
\text { surface 'habitats' }\end{array}$ & $\begin{array}{l}\text { Advantageous characteristics } \\
\text { of the hypolithic habitat }\end{array}$ & Possible benefits of hypolithic 'lifestyle' & Reference \\
\hline High light intensity & Low light intensity & $\begin{array}{l}\text { Reduced photobleaching, reduced } \\
\text { energy burden from synthesis of } \\
\text { sunscreen pigments }\end{array}$ & Cockell et al. 2008 \\
\hline High incident $\mathrm{UV}_{\mathrm{A} / \mathrm{B}}$ & Reduced incident $\mathrm{UV}_{\mathrm{A} / \mathrm{B}}$ & Reduced cellular damage & Cockell et al. 2008 \\
\hline $\begin{array}{l}\text { Rapid high amplitude } \\
\text { humidity fluctuations }\end{array}$ & Buffering of atmospheric humidity & Reduced desiccation pressure & Khan 2009 \\
\hline $\begin{array}{l}\text { Rapid high amplitude } \\
\text { thermal fluctuations }\end{array}$ & Thermal buffering & Reduced freeze-thaw damage & Khan 2009 \\
\hline Low water availability & Condensation surfaces & Higher water availability & Warren-Rhodes et al. 2006 \\
\hline $\begin{array}{l}\text { Low atmospheric } \mathrm{CO}_{2} \\
\text { concentrations }\end{array}$ & Elevated local $\mathrm{CO}_{2}$ concentrations? & Higher growth rates? & $\begin{array}{l}\text { No evidence for this suggested } \\
\text { 'benefit' has been reported }\end{array}$ \\
\hline $\begin{array}{l}\text { Physical instability } \\
\text { (aeolian effects) }\end{array}$ & Physical stability & Reduced community disruption & Warren-Rhodes et al. 2007 \\
\hline
\end{tabular}

\section{Methods}

\section{Field survey}

All data were collected during field expeditions to the McMurdo Dry Valleys in the 2005-08 (inclusive) summer seasons. Hypolithic community surveys were principally focussed on the desert pavements of the upper Miers Valley $\left(78^{\circ} 45^{\prime} \mathrm{S}, 163^{\circ} 15^{\prime} \mathrm{E}\right)$, on both the north- and south-facing valley walls over an altitude range of $170 \mathrm{~m}$ (valley floor at the western end of Lake Miers) to $634 \mathrm{~m}$ (northern ridgeline). More limited surveys were also undertaken in the neighbouring Marshall Valley and Shangri La region, at Marble Point, the Labyrinth (Upper Wright Valley) and the Beacon Valley. Quartz and marble pebbles were readily identified visually, owing to the pale colouration of both mineral types. Selected hypolithons were photographed and collected by sterile transfer to WhirlPak ${ }^{\circledR}$ bags.

Different hypolithic community 'classes' were identified in the field on the basis of gross morphological properties (see below), and the identification was supported by on-site light microscopy (Olympus). For field identification, a 'key' was routinely employed (Table II).

\section{Molecular phylogenetics}

Phylogenetic marker genes (16S rRNA and 18S rRNA genes) were amplified from hypolithon metagenomic DNA extracts (primer sets E9F+U1510R and EUKA+EUKB, respectively) (Reysenbach \& Pace 1995, Hansen et al. 1998, Diez et al. 2001) and cloned directly into the pTZ57R/T vector (Fermentas). Insert DNA was sequenced using the MegaBACE 500 Automated Capillary DNA Sequencing System (Amersham Biosciences). Sequences were edited using Chromas (Technelysium) and assembled in DNAMAN Version 4.15 (Lynann Biosoft) before submission to the NCBI database. The BlastN function was used to detect related sequences.

\section{Results and discussion}

\section{Hypolithon distribution}

The upper Miers Valley and neighbouring Shangri La regions are rich in quartz and marble outcrops, providing numerous small quartz stones (and less abundant marble) suitable for hypolithic community development. The laminar structure of the outcrops commonly generates fragments with near-flat upper and lower surfaces, and a crystalline depth of 2-4 cm. All hypolithic communities observed in this study were found beneath quartz and marble rocks with an upper surface area of $>4 \mathrm{~cm}^{2}(c .2 \times 2 \mathrm{~cm})$ (Appendix A) and partially embedded in the soil as components of the desert pavement (Fig. 1a). It is thought that smaller translucent rocks $\left(<c .4 \mathrm{~cm}^{2}\right)$ do not present a physically stable microenvironment and are therefore

Table II. Key for identification of hypolithic community types.

\begin{tabular}{|c|c|c|c|}
\hline Type & Cyanobacteria & Fungal mycelium & Moss plantlets \\
\hline I (cyanobacterial) & $\begin{array}{l}\text { Present as green/orange cellular material, } \\
\text { adhering intimately to underside and/or } \\
\text { sides of translucent rocks }\end{array}$ & Not visible & Not visible \\
\hline II (fungal) & $\begin{array}{l}\text { May be present (see above) but often } \\
\text { not visible }\end{array}$ & $\begin{array}{l}\text { Fibrous network entraining sand grains and } \\
\text { always cemented to the underside of the rock }\end{array}$ & Not visible \\
\hline III (moss) & May be present (see above) & Not visible & $\begin{array}{c}\text { Embedded in the soil and evident as } \\
\text { a red/brown or green surface layer } \\
\text { on removal of the overlying rock }\end{array}$ \\
\hline
\end{tabular}



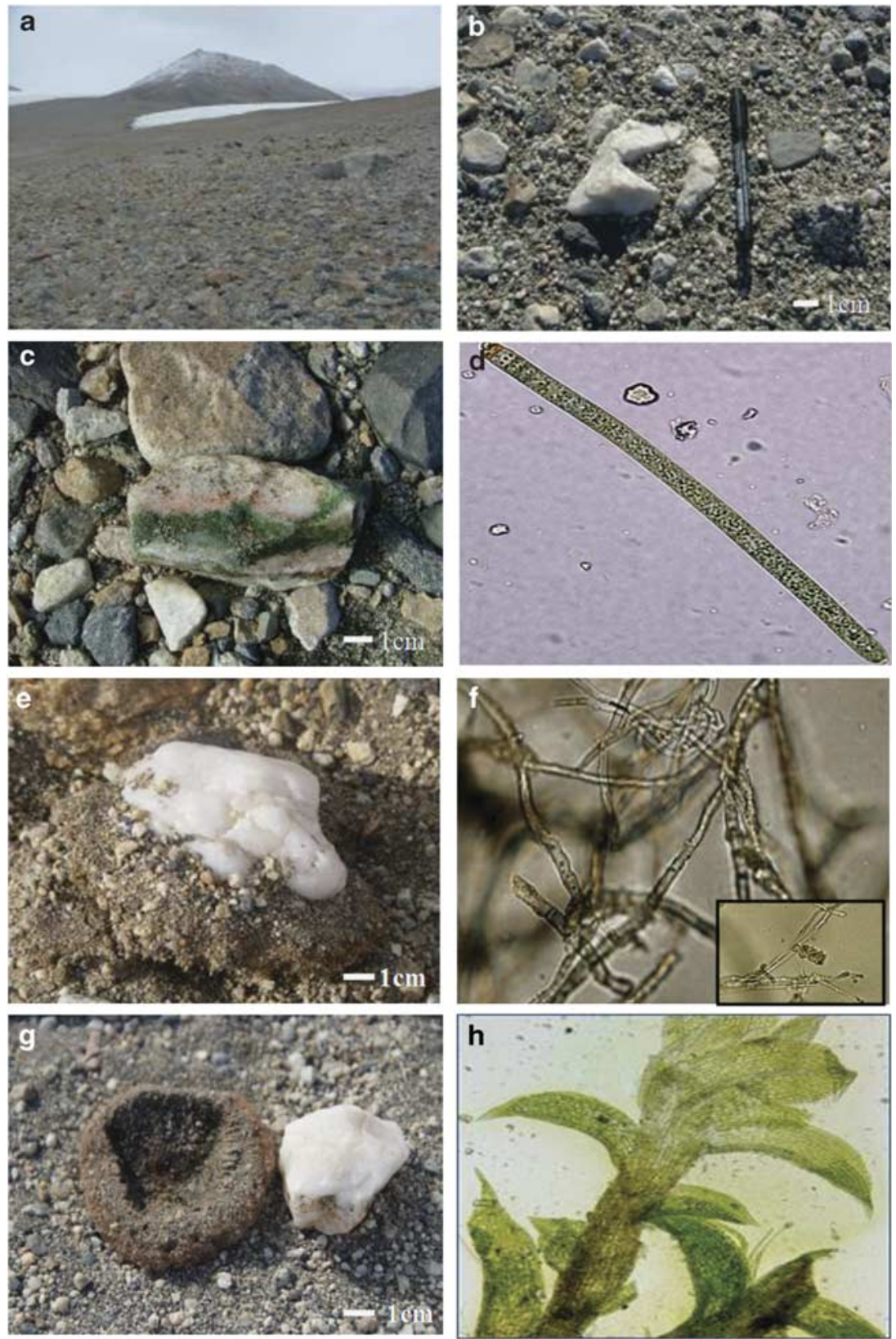

Fig. 1. a. Typical Miers Valley desert pavement with b. embedded hypolithic quartz rock. c. Type I hypolithic communities are dominated by cyanobacteria, d. often Oscillatoriales sp. e. Type II (fungal-dominated) hypolithic communities. f. Light micrographs of structural filaments of Type II communities at 100x magnification. g. Type III (moss-dominated) hypolithic communities, and h. light micrograph (100x magnification) of the moss Hennediella heimii found in Type III hypolithic communities.

(Pictures by D.A. Cowan and N. Khan, microscopy by S.A. Wood and S.B. Pointing).

not commonly colonized. It is notable that the overlying rock typically shows no surface evidence of the subsurface community type (e.g. Fig. 1b), which is only revealed by removal of the rock from the soil.

The distribution of hypolithons was not homogenous across the valley systems, but was essentially dependent on the location of suitable quartz and marble outcrops. The highest abundance of hypolithons was found in the vicinity and downslope of such outcrops, where frequencies were as high as 5 per $\mathrm{m}^{2}$ (equivalent to $c .140 \mathrm{~cm}^{2}$ of rock surface, or $1.4 \%$ total ground surface area). Across the region, average hypolithon distribution was more commonly $0.1-0.5$ per $\mathrm{m}^{2}$ (0.03-0.14\% of total surface area). Broady (1981) showed hypolithic community coverage in the typical dry mineral soils in the Vestfold Hills, Antarctica to average $66 \mathrm{~cm}^{2} \mathrm{~m}^{-2}$. In McKelvey Valley, a high altitude location within the 
McMurdo Dry Valleys, colonization was recorded as 4.9\%, although this rose to $22 \%$ where soils were impacted by snowmelt (Pointing et al. 2009). In an extensive biological survey undertaken across Garwood, Marshall and Miers valleys in the lower McMurdo Dry Valleys region during the 2008 summer, hypolithons were identified in 38\% of the 439 recorded transects (Antarctica New Zealand Event K020, unpublished results). For the entire survey area $\left(c .250 \mathrm{~km}^{2}\right)$ and using the average recorded hypolithon coverage of $25 \mathrm{~cm}^{2}$ $40 \mathrm{~m}^{-2}$ transect, we calculate the total regional hypolithon coverage to be $c .1562 \mathrm{~m}^{2}$. As the terrestrial ecosystem in the region is devoid of vascular plants, photosynthesizing hypolithic communities can be considered major contributors to productivity (in terms of carbon assimilation) in the region.

\section{Hypolithon structures}

Based on extensive field observations, supported by microscopic and phylogenetic analyses, we suggest that hypolithic communities in the Miers Valley can be divided into three morphological types or classes: Type I: Cyanobacterialdominated communities, Type II: Fungal-dominated communities, Type III: Moss-dominated communities.

Cyanobacterial-dominated communities (Type I) were evident as pigmented biofilms adhering intimately to the underside and submerged sides of translucent rocks (Fig. 1c $\&$ d). Both green and red/orange pigmented zones were sometimes evident (Fig. 1c). While Type I communities were commonly associated with quartz substrates, they were also the only hypolithic community type associated with other translucent rock types (e.g. marble) recorded at various McMurdo Dry Valley sites (Miers Valley, Marble Point, Labyrinth-Upper Wright Valley). These Type I hypolithic communities may have the lowest light requirement, as the translucency of marble is very much lower than quartz of similar dimension (typically below the detection limits of a quantum light meter).

Analysis of community rDNA from Type I hypolithons revealed cyanobacterial phylotypes were largely from two orders: Nostocales (Genbank accession numbers HM490249, HM490250, HM490254-HM490256) and Oscillatoriales (Leptolyngbya sp., Genbank accession numbers HM490251 to HM490253, HM490257, HM490258), which together comprised c. $45 \%$ of the cyanobacterial sequences detected (Khan 2009).

Type II communities were structurally very distinct from other hypolithic communities. These communities were firmly 'cemented' (adherent) to the underside of the quartz rock (Fig. 1e). The preliminary identification of this hypolithon type may be predicted in situ with some accuracy by physically testing the mobility of the embedded quartz rock. Rocks harbouring Type I and III hypolithic communities often rotated with relatively little manual pressure, whereas Type II communities impart a perceptible resistance to physical rotation. Once removed from the embedded position in the soil, Type II communities were extremely fragile and crumbled readily with either shock or pressure. The community appeared as a loose structure of mineral particles held in place by a network of fine filaments (Fig. 1e). Microscopy showed branched fungal mycelia-like structures (Fig. 1f) loosely associated with green-pigmented algal cell clusters (Fig. 1f, inset). Ongoing phylogenetic studies indicate that cyanobacterial and chlorophyte phylotypes are also recoverable from Type II hypolithons. Type II communities showed no visual evidence of photosynthetic macro-organisms (e.g. mosses).

Type III communities were physically dominated by mosses (Fig. 1g). These communities did not adhere to the rock surface, but occurred directly underneath the rock with the perimeter of the community generally mirroring that of the overlying rock. Removal of the overlying rock exposed the upper surface of the moss community, where the tips of the moss leaves were visible as a greenish layer (Fig. 1g). The Type III communities were relatively resistant to fragmentation and were readily recovered in an unbroken state. The bright green colour of the chlorophyll-rich leaf tips (Fig. 1h) suggested that these mosses were viable and actively photosynthesizing at the point of sampling. The mossdominated structures provided a lattice network which holds mineral particles, constituting a high proportion of the total mass of the physical community. Phylogenetic analyses have shown that moss species from Moss Superclass V, such as Bryum argenteum Hedw. (Genbank accession numbers HM490214-HM490227) dominate these communities (Khan 2009). Morphological characterization has also shown that other Moss Superclass V species such as Hennediella heimii (Hedw.) Zand. are also present (R. Herbert, personal communication 2009). It is of note that we have also recently described hypoliths supporting lichen mycobiont and phycobiont and mosses from the high altitude tundra of Tibet (Wong et al. 2010). The possibility that hypoliths supporting mosses are a feature of cold deserts on a wider scale therefore also arises.

\section{Relationships and evolution of hypolithic communities}

The presence of a hypolithic community (irrespective of type) under virtually every translucent rock of suitable type and size in the Miers, Marshall and Garwood valleys suggests that the development of these communities is not dependent on a complex and occasional set of environmental and biological factors. This observation suggests that the capacity for hypolithic community development is ubiquitous in these lower McMurdo Dry Valley regions; i.e. cells, spores and/or propagules which are recruited to establish the structural hypolithic community are either already present or rapidly acquired (e.g. via aeolian transport). However, it is not clear what factors control the development of one, rather than another, hypolithic community type. Several possible developmental routes are clearly possible (Fig. 2). The community types may evolve completely independently 
a

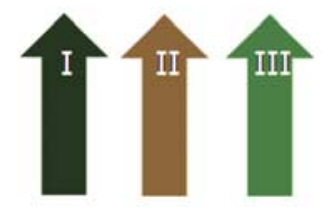

Parallel development b

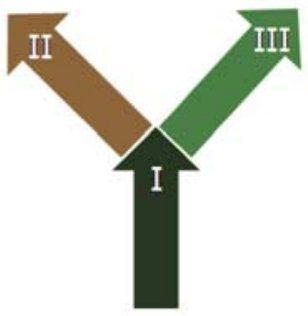

Bifurcating development c

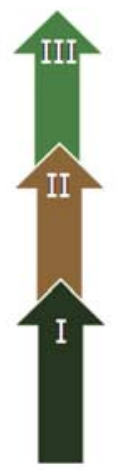

Sequential development
Fig. 2. Hypothetical pathways for the development of hypolithic communities.

(Fig. 2a), where the process is dictated by specific environmental requirements (positive control) or limitations (negative control). For example, the observation that only Type I hypolithons occur under rock types with low light transmission is suggestive that community development for Types II and III hypolithons is under positive control and that a minimum level of light transmission is a critical factor. Alternatively, community development may be linked and the three types may represent stages in succession (Fig. $2 b \&$ c). The progression of such a developmental pathway could be dictated by relative growth rates or by more complex factors such as modifications of growth environments by one developmental state as a prerequisite for development of the next. It seems likely that Type I hypolithons represent the basal developmental state.

This view is supported, albeit without an extensive dataset, by the results of an in situ hypolithic community growth rate experiment established at a site in the Miers Valley in January 2005. Quartz rocks harbouring hypolithic communities (the types were not recorded) were collected, cleaned and sterilized by ethanol swabbing, and repositioned on open soil at a site where hypolithons were relatively common (estimated $0.1-0.2$ per $\mathrm{m}^{2}$ ). Evidence of growth was assessed visually after 12 months (January 2006) and again after 48 months (January 2009). After 12 months, a single quartz rock showed signs of early Type I (cyanobacterial) community development (Fig. 3a). The visual appearance of two nascent hypolithons after 48 months, most notably the cemented characteristic, was typical of a Type II (fungal) community.

The apparent lack of a dominant photoautotrophic component in Type II (fungal) hypolithic communities raises intriguing questions on the trophic structure of this community. The most common hypothesis is that autotrophs are the primary organisms in succession due to the lack of organic carbon present for the development of heterotrophic communities (Walker \& del Moral 2003). Carbon fixation by autotrophs results in an increase in carbon available and the development of heterotrophic communities that drive decomposition and nutrient cycling in the ecosystem (Bardgett \& Walker 2004, Bardgett et al. 2005). However, recent studies have shown that diverse heterotrophic microbial communities occur in low carbon environments before the establishment of autotrophic communities (Tscherko et al. 2003). Furthermore, ancient carbon has been shown to sustain heterotrophic microbial communities in low carbon environments in Antarctica (Hopkins et al. 2006). The open soils surrounding hypolithic communities have been shown to harbour diverse heterotrophic organisms (Smith et al. 2006), some of which are common to hypolithic populations (Khan 2009). Under the favourable environmental conditions of the hypolithic niche, open soil communities are likely to contribute to the successional development of hypolithic communities, but do not necessarily drive the process.

One possible model which could incorporate both developmental and trophic elements would position Type II hypolithons as an intermediate developmental state between Type I and III. A possible developmental pathway would involve the establishment of a localized fixed carbon pool, driven by the dominant cyanobacterial composition of the Type I community. The elevated heterotrophic carbon availability would then drive the development of an essentially (but not solely) heterotrophic Type II community. This is consistent with recent studies in low carbon glaciated sites in the Austrian Alps which showed that the abundance of fungi relative to bacteria within the soil microbial community increased as succession proceeded and resources availability
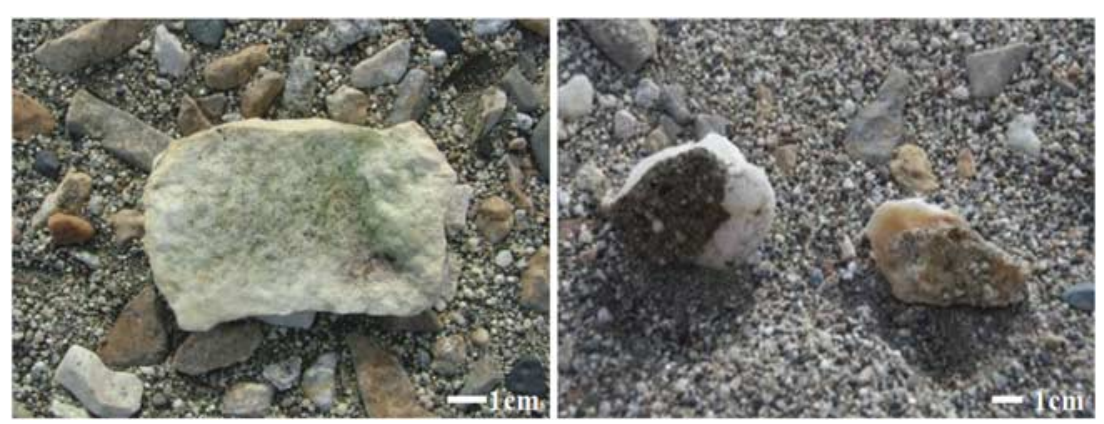

Fig. 3. Evidence for growth of hypolithic communities. a. 12 month development, b. 48 month development (photographs by DA Cowan and N Khan). 
(i.e. carbon) increased (Bardgett et al. 2005, 2007). The structural stabilization of the hypolithic zone by the fungal mycelia might facilitate the subsequent development of a Type III community, placing the moss-dominated consortium as the successional 'climax' community. We therefore propose as a working hypothesis that a possible developmental pathway for hypolithic communities is that represented in Fig. 2c. While the driving forces for this developmental pathway are uncertain, we speculate that founder trophic effects (Halkka et al. 1974, Cordonnier et al. 2006) are possible causative agents. The increased eutrophication of the hypolithic microenvironment resulting from cyanobacterial (founder) colonization may be a trigger for heterotrophic fungal colonization and/or for moss germination.

We also note that the 'growth' experiment suggests that the developmental timescales for 'mature' communities are probably in the order of $<1$ year (Type I) and 1-4 years (Type II). As yet we have no data to provide a putative timescale for the development of Type III communities. However, given the slow growth rates for Antarctic mosses (Skotnicki et al. 2000), we predict that Type III hypolithons may develop over periods of $10-50$ years. This projection has the merit of being testable by carbon dating of communities (e.g. Bardgett et al. 2007) or by longer time-scale monitoring of population compositions in model hypolithic environments.

\section{Acknowledgements}

This research was undertaken under the auspices of the South African National Antarctic Programme; the New Zealand Antarctic Research Programme under Antarctica New Zealand and the Waikato University Antarctic Terrestrial Biology Research Program. The authors gratefully acknowledge funding from the National Research Foundation (SA), the Hong Kong Research Grants Council (7733/08 M) and the NZ Foundation for Research Science \& Technology (Terrestrial Antarctic Biocomplexity Survey, nzTABS). We gratefully acknowledge Susie Woods (Cawthron Institute, Nelson, NZ) for provision of the electron micrographs.

\section{References}

Aislabie, J.M., Chhour, K.-L., Saul, D.J., Miyauchi, S., Ayton, J., PaEtzold, R.F. \& Balks, M.R. 2006. Dominant bacteria in soils of Marble Point and Wright Valley, Victoria Land, Antarctica. Soil Biology \& Biochemistry, 38, 3041-3056.

BARDGETT, R.D. \& WALKER, L.R. 2004. Impact of coloniser plant species on the development of decomposer microbial communities following deglaciation. Soil Biology \& Biochemistry, 36, 555-559.

Bardgett, R.D., Bowman, W.D., Kaufmann, R. \& Schmidt, S.K. 2005. A temporal approach to linking aboveground and belowground ecology. Trends in Ecology \& Evolution, 20, 634-641.

Bardgett, R.D., Richter, A., Bol, R., Garnett, M.H., Baumler, R., Xu, X., Lopez-Capel, E., Manning, D.A.C., Hobbs, P.J., Hartley, I.R. \& WANEK, W. 2007. Heterotrophic microbial communities use ancient carbon following glacial retreat. Biology Letters, 3, 487-490.
Berner, T. \& Evenari, M. 1978. The influence of temperature and light penetration on the abundance of the hypolithic algae in the Negev Desert of Israel. Oecologia, 33, 255-260.

Bоскнеiм, J.G. 1997. Properties and classification of cold desert soils from Antarctica. Soil Science Society of America Journal, 61, 224-231.

Boyd, W.L., Rothenberg, I. \& Boyd, J.W. 1970. Soil microorganisms at Paradise Harbor, Antarctica. Ecology, 51, 1040-1045.

BROADY, P.A. 1981. The ecology of sublithic terrestrial algae at the Vestfold Hills, Antarctica. British Phycological Journal, 16, 231-240.

BROADY, P.A. 2005. The distribution of terrestrial and hydro-terrestrial algal association at three contrasting locations in southern Victoria Land, Antarctica. Algalogical Studies, 118, 95-112.

Cameron, R., Morelli, F.A. \& Johnson, R.M. 1972. Bacterial species in soil and air of the Antarctic continent. Antarctic Journal of the United States, 7, 187-189.

Cockell, C.S. \& Stokes, M.D. 2004. Widespread colonization by polar hypoliths. Nature, 431, 414.

Cockell, C.S., McKay, C.P., Warren-Rhodes, K. \& Horneck, G. 2008. Ultraviolet radiation-induced limitation to epilithic microbial growth in arid deserts: dosimetric experiments in the hyperarid core of the Atacama Desert. Journal of Photochemistry \& Photobiology, B90, 79-87.

Cordonnier, T., Courband, B. \& Franc, A. 2006. The effect of colonization and competition processes on the relation between disturbance and diversity in plant communities. Journal of Theoretical Biology, 243, 1-12.

Cowan, D.A. \& Aн Tow, L. 2004. Endangered Antarctic environments. Annual Reviews in Microbiology, 58, 649-690.

Cowan, D.A., Russell, N.J., Mamais, A. \& Sheppard, D.M. 2002. Antarctic dry valley mineral soils contain unexpectedly high levels of microbial biomass. Extremophiles, 6, 431-436.

Diez, B., Pedros-Alio, C., Marsh, T.L. \& Massana, R. 2001. Application of denaturing gradient gel electrophoresis (DGGE) to study the diversity of marine picoeukaryotic assemblages and comparison of DGGE with other molecular techniques. Applied \& Environmental Microbiology, 67, 2942-2951.

FriedmanN, E.I. \& OCAMPo, R. 1976. Endolithic blue-green algae in the dry valleys: primary producers in the Antarctic desert ecosystem. Science, 193, 1247-1249.

Halkka, O., Raatikainen, M. \& Halkka, L. 1974. The founder principle, founder selection, and evolutionary divergence and convergence in natural populations of Philaenus. Hereditas, 78, 73-84.

Hansen, M.C., Tolker-Nielsen, T., Givskov, M. \& Molin, S. 1998. Biased 16S rDNA PCR amplification caused by interference from DNA flanking the template region. FEMS Microbiology Ecology, 26, $141-149$.

Hopkins, D.W., Sparrow, A.D., Elberling, B., Gregorich, E.G., Novis, P.M., Greenfield, L.G. \& Tilston, E.L. 2006. Carbon, nitrogen and temperature controls on microbial activity in soils from an Antarctic dry valley. Soil Biology \& Biochemistry, 38, 3130-3140.

Hughes, K.A. \& Lawley, B. 2003. A novel Antarctic microbial endolithic community within gypsum crusts. Environmental Microbiology, 5, $555-565$.

KHAN, N. 2009. Characterisation of microbial communities associated with hypolithic environments in Antarctic dry valley soils. $\mathrm{PhD}$ thesis, University of the Western Cape, 216 pp. [Unpublished.].

Nienow, J.A. \& Friedmann, E.I. 1993. Terrestrial lithophytic (rock) communities. In Friedmann, E.I., ed. Antarctic microbiology. New York: Wiley-Liss, 343-412.

Onofri, S., Selbmann, L., Zucconi, L. \& Pagano, S. 2004. Antarctic microfungi as models for exobiology. Planetary \& Space Science, $\mathbf{5 2}$, 229-237.

Pointing, S.B., Warren-Rhodes, K.A., Lacap, D.C., Rhodes, K.L. \& McKaY, C.P. 2007. Hypolithic community shifts occur as a result of liquid water availability along environmental gradients in China's hot and cold hyperarid deserts. Environmental Microbiology, 9, 414-424. 
Pointing, S.B., Chan, Y., Lacap, D.C., Lau, M.C.Y., Jirgens, J.A. \& FARRELL, R.L. 2009. Highly specialized microbial diversity in hyper-arid polar desert. Proceedings of the National Academy of Science of the United States, 106, 19 964-19969.

Reysenbach, A.-L. \& PACE, N.R. 1995. Reliable amplification of hyperthermophilic archaeal 16S rRNA genes by the polymerase chain reaction. In RobB, F.T. \& Place, A.R., eds. Archaea: a laboratory manual - thermophiles. Cold Spring Harbour, NY: Cold Spring Harbour Laboratory Press, 101-107.

Schlesinger, W.H., Pippen, J.S., Wallenstein, M.D., Hofmockel, K.S., Klepeis, D.M. \& Mahall, B.E. 2003. Community composition and photosynthesis by photoautotrophs under quartz pebbles, southern Mojave Desert. Ecology, 84, 3222-3231.

Skotnicki, M.L., Ninham, J.A. \& Selkirk, P.M. 2000. Genetic diversity, mutagenesis and dispersal of Antarctic mosses - a review of progress with molecular studies. Antarctic Science, 12, 363-373.

Smith, J.J., Ah Tow, L., Stafford, W., Cary, C. \& Cowan, D.A. 2006. Bacterial diversity in three different Antarctic cold desert mineral soils. Microbial Ecology, 51, 413-421.

Smith, M.C., Bowman, J.P., Scott, F.J. \& Line, M.A. 2000. Sublithic bacteria associated with Antarctic quartz stones. Antarctic Science, 12, $177-184$.
Tscherko, D., Rustemeier, J., Richter, A., Wanek, W. \& Kandeler, E. 2003. Functional diversity of the soil microflora in primary succession across two glacier forelands. European Journal of Soil Science, 54, 685-696.

Vishniac, H.S. 1993. The microbiology of Antarctic soils. In Friedmann, E.I., ed. Antarctic microbiology. New York: Wiley-Liss, 343-412.

Walker, L.R. \& del Moral, R. 2003. Primary succession and ecosystem rehabilitation. Cambridge: Cambridge University Press, 456 pp.

Warren-Rhodes, K.A., Rhodes, K.L., Pointing, S.B., Ewing, S.A., Lacap, D.C., Gomez-Silva, B., Amundson, R., Friedmann, E.I. \& McKay, C.P. 2006. Hypolithic cyanobacteria, dry limit of photosynthesis, and microbial ecology in the hyperarid Atacama Desert. Microbial Ecology, 52, 389-398.

Warren-Rhodes, K.A., Rhodes, K.L., Boyle, L.N., Pointing, S.B., Chen, Y., Liu, S., Zhuо, P. \& McKay, C.P. 2007. Cyanobacterial ecology across environmental gradients and spatial scales in China's hot and cold deserts. FEMS Microbiology Ecology, 61, 470-482.

Wood, S.A., Rueckert, A., Cowan, D.A. \& CARy, S.C. 2008. Sources of edaphic cyanobacterial diversity in the dry valleys of eastern Antarctica. The ISME Journal, 2, 308-320.

Wong, K.Y., LaU, M.C.Y., Lacap, D.C., Aitchison, J.C., Cowan, D.A. \& Pointing, S.B. 2010. Hypolithic colonization of quartz pavement in the high altitude tundra of central Tibet. Microbial Ecology, 10.1007/ s00248010-9653-2.

Appendix A. Dimensions of hypolithic quartz rocks collected in the Miers Valley (January 2008).

\begin{tabular}{llr}
\hline Sample & $\begin{array}{c}\text { Dimensions } \\
(1 \times \mathrm{w} \times \mathrm{cm})\end{array}$ & $\begin{array}{c}\text { Footprint } \\
\left(\mathrm{cm}^{2}\right)\end{array}$ \\
\hline MVH08-01A & $6.05 \times 3.2 \times 1.2$ & 19.4 \\
MVH08-02A & $5.2 \times 5.1 \times 3$ & 26.5 \\
MVH08-03A & $5.8 \times 4.9 \times 3.4$ & 28.4 \\
MVH08-04A & $5.0 \times 4.0 \times 3.2$ & 17.8 \\
MVH08-05A & $5.4 \times 3.3 \times 2.9$ \\
MVH08-06A & $5.3 \times 3.5 \times 2.7$ \\
MVH08-07A & $5.2 \times 3.0 \times 3.1$ \\
MPH08-01A & $6.7 \times 5.2 \times 3.1$ \\
MVH08-08A & $7.4 \times 4.4 \times 3.3$ \\
MVH08-10A & $8 \times 4.8 \times 1.8$ \\
MVH08-11A & $6.1 \times 4.7 \times 2.8$ \\
MVH08-12A & $5.5 \times 3.1 \times 2.2$ \\
MVH08-13A & $7.2 \times 5.5 \times 2.4$ \\
MVH08-15A & $5.3 \times 3.5 \times 0.9$ \\
MVH08-16A & $9.5 \times 6.7 \times 2$ \\
MVH08-17A & $6.1 \times 5.7 \times 2.7$ \\
MVH08-18A & $6.7 \times 6.0 \times 5.2$ \\
MVH08-19A & $4.3 \times 3.8 \times 2.6$ \\
MVH08-20A & $3.9 \times 3.9 \times 2.8$ \\
MVH08-21A & $6.0 \times 3.3 \times 2.5$ \\
MVH08-22A & $3.5 \times 2.9 \times 1.6$ \\
\hline AV1 & 32.6 \\
\hline
\end{tabular}

Average area $\left(\mathrm{cm}^{2}\right)=27.3 \pm 12.7(n=21)$. 